\title{
Growth Regulation and Tank Mixing Associated with a Glyphosate-tolerant Perennial Ryegrass Cultivar
}

\author{
Christian M. Baldwin ${ }^{1,3}$, A. Douglas Brede ${ }^{2}$, and Jami J. Mayer ${ }^{2}$
}

ADDITIONAL INDEX WORDs. annual bluegrass, bermudagrass, clipping yield, Cynodon dactylon, herbicide tolerance, Lolium perenne, nitrogen, perennial ryegrass, plant growth regulator, Poa annua

SUMMARY. With the emergence of glyphosate-tolerant cultivars, identifying management strategies not applicable with older cultivars need to be revisited. Objectives of these research trials were to quantify the growth regulation effects following a glyphosate application and to determine the safety of tank mixing glyphosate with another herbicide, various nitrogen $(\mathrm{N})$ sources, and a plant growth regulator (PGR) on a glyphosate-tolerant perennial ryegrass [PRG (Lolium perenne L.)] cultivar, Replay. In the growth regulation trial, glyphosate was applied at 0 to $1.03 \mathrm{lb} /$ acre, whereas PGRs flurpimidol, trinexapac-ethyl, paclobutrazol, and trinexapac-ethyl + flurpimidol were applied at $0.50,0.18,0.37$, and $0.09+0.22 \mathrm{lb} /$ acre, respectively, on 15 July 2010 and 2 Aug. 2012. In the tank mixing trial, dicamba $(0.50 \mathrm{lb} / \mathrm{acre})$, urea (15 lb/acre $\mathrm{N})$, and ammonium sulfate [AMS (15 lb/acre N)] were applied alone or tank mixed with glyphosate at 0 to $0.52 \mathrm{lb} /$ acre. Tank mixing urea with glyphosate had minimal effect on PRG color, while adding AMS consistently improved color at the highest glyphosate rate of $0.52 \mathrm{lb} /$ acre. Twenty days following a glyphosate application, only rates $>0.40 \mathrm{lb} /$ acre resulted in significant growth regulation compared with untreated plots. This study indicates that tank mixing glyphosate with another herbicide, a PGR, and various $\mathrm{N}$ sources appear safe to the glyphosate-tolerant PRG cultivar. Also, the growth regulating effects of glyphosate applications would serve as an additional benefit to annual bluegrass (Poa annua L.) control reported in previous trials.

$\mathrm{T}$ The development of two glyphosate-tolerant PRG cultivars, JS501 and Replay, provides a unique avenue for weed control (Samudio et al., 2011). A previous field trial established these cultivars can tolerate glyphosate rates up to $0.81 \mathrm{~kg} \cdot \mathrm{ha}^{-1}$ with minimal stand injury when applied to actively growing PRG (Baldwin et al., 2012). However, tolerance levels are reduced to $\approx 0.27$ $\mathrm{kg} \cdot \mathrm{ha}^{-1}$ when applied during the fall season and applications at rates $>0.29$ $\mathrm{kg} \cdot \mathrm{ha}^{-1}$ should be avoided until the plants are beyond the four-leaf stage (Baldwin et al., 2015). In a greenhouse trial, Flessner et al. (2014) noted a glyphosate rate of $2.60 \mathrm{~kg} \cdot \mathrm{ha}^{-1}$ was required to achieve $50 \%$ visible injury, which was four times higher when compared with standard, nontolerant PRG cultivars.

\footnotetext{
Approved for publication as Journal Article No. J-12566 of the Mississippi Agricultural and Forestry Experiment Station, Mississippi State University.

${ }^{1}$ Department of Plant Soil Sciences, Mississippi State University, 32 Creelman Street, 117 Dorman Hall, Mississippi State, MS 39762

${ }^{2}$ Jacklin Seed by Simplot, 5300 West Riverbend Avenue, Post Falls, ID 83854

${ }^{3}$ Corresponding author. E-mail: cmb907@msstate.edu.
}

The use of glyphosate applied over actively growing turfgrass has received little attention due to the lack of glyphosate-tolerant cultivars commercially available. Primarily, the focus has determined thresholds for tolerance (Baldwin et al., 2012; Dant et al., 2005; Flessner et al., 2014; Hart et al., 2005) with little published data regarding possible benefits of glyphosate applications, in particular, growth regulation. Although glyphosate is considered a class D PGR (Ervin and Zhang, 2008), its use as a PGR for growth regulation has historically been limited to low-maintenance sites where injury can be tolerated. Previous work in canola (Brassica napus L.) and soybean (Glycine max L.) demonstrated a reduction in shoot weight following an application of glyphosate (Cakmak et al., 2009; Schilling et al., 2006).

Combining various products, such as herbicides, PGRs, or foliar fertilizers into one tank has become a common practice in the turfgrass industry. Regarding herbicides, combining different modes of action can potentially increase the spectrum of weed control and prevent the development of herbicide resistant weeds by altering selection pressure. This is relevant when considering the use of glyphosate-tolerant cultivars in fine turf management for annual bluegrass $(A B G)$ control since recent reports have noted resistant $A B G$ biotypes in golf course fairways due to repeated glyphosate applications (Binkholder et al., 2011; Brosnan et al., 2012).

Several studies in turfgrass have documented the benefits of tank mixing herbicides, PGRs, and $\mathrm{N}$ sources. Jeffries et al. (2013) noted beneficial effects of tank mixing an early gibberellic inhibiting PGR, paclobutrazol (PB), with a photosystem II-inhibiting herbicide, amicarbazone. The authors reported increased ABG control, safety to the desirable species, and fewer overall applications were necessary for acceptable weed control. Elmore et al. (2013) also noted improved ABG control when tank mixing mesotrione and amicarbazone compared with each herbicide applied alone. Finally, Kaminski and Putman (2009) reported tank mixing an iron $+\mathrm{N}$ product with bispyribacsodium herbicide masked chlorosis on 'Allister' colonial bentgrass (Agrostis capillary L.) compared with bispyribac-sodium applied alone.

With the emergence of glyphosate-tolerant cultivars, growth regulation and herbicide options must be revisited to identify management strategies not applicable with older cultivars. Young et al. (2003) applied glyphosate at $0.84 \mathrm{~kg} \cdot \mathrm{ha}^{-1}$ with and without AMS at $20 \mathrm{~g} \cdot \mathrm{L}^{-1}$. This study

\begin{tabular}{llll}
\hline $\begin{array}{l}\text { Units } \\
\text { To convert U.S. to SI, } \\
\text { multiply by }\end{array}$ & U.S. unit & SI unit & $\begin{array}{l}\text { To convert SI to U.S., } \\
\text { multiply by }\end{array}$ \\
\hline 0.3048 & $\mathrm{Ft}$ & $\mathrm{m}$ & 3.2808 \\
2.54 & inch $(\mathrm{es})$ & $\mathrm{cm}$ & 0.3937 \\
1.1209 & $\mathrm{lb} / \mathrm{acre}$ & $\mathrm{kg} \cdot \mathrm{ha}^{-1}$ & 0.8922 \\
305.1517 & $\mathrm{oz} / \mathrm{ft}^{2}$ & $\mathrm{~g} \cdot \mathrm{m}^{-2}$ & 0.0033 \\
7.4892 & $\mathrm{Oz} / \mathrm{gal}$ & $\mathrm{g} \cdot \mathrm{L}^{-1}$ & 0.1335 \\
$\left({ }^{\circ} \mathrm{F}-32\right) \div 1.8$ & ${ }^{\circ} \mathrm{F}$ & ${ }^{\circ} \mathrm{C}$ & $\left({ }^{\circ} \mathrm{C} \times 1.8\right)+32$
\end{tabular}


showed no improvement in glyphosate absorption and translocation by adding AMS to glyphosate when applied to common lambsquarters (Chenopodium album L.); however, similar applications resulted in a significant increase in glyphosate efficiency when applied to velvetleaf (Abutilon theophrasti Medik.). It appears, the addition of AMS to glyphosate is species dependent regarding glyphosate efficiency. Bradley et al. (2000) sprayed glyphosate at 0.43 and $0.84 \mathrm{~kg} \cdot \mathrm{ha}^{-1}$ with or without the addition of AMS at $3.8 \mathrm{~kg} \cdot \mathrm{ha}^{-1}$. The authors noted increased control of 'Rox Orange' forage sorghum (Sorghum bicolor $\mathrm{L}$.) with the addition of AMS at the $0.43 \mathrm{~kg} \cdot \mathrm{ha}^{-1}$ rate; however, no differences were noted at the higher application rate.

Since reduced inputs, such as reduced mowing, is an important management consideration and tank mixing multiple products is a common practice in turfgrass management, the objectives of this study were to quantify potential growth regulation following a glyphosate application to a glyphosate-tolerant cultivar and determine the safety of tank mixing an alternative active ingredient, various $\mathrm{N}$ sources, and a PGR with glyphosate on a glyphosatetolerant PRG cultivar.

\section{Materials and methods}

Growth Regulation. Field trials at the Jacklin Seed research farm in Post Falls, ID (lat. $47^{\circ} 44^{\prime} 46^{\prime \prime} \mathrm{N}$, long. $\left.116^{\circ} 52^{\prime} 56^{\prime \prime} \mathrm{W}\right)$, compared the growth regulation of 'Replay' PRG following various glyphosate application rates and PGRs. Before treatment initiation, both study areas were sprayed with glyphosate at $1.55 \mathrm{lb} /$ acre, scalped to 0.14 inch (Greens King 500 Series; Jacobsen, Charlotte, NC), and verticut in two directions with 1 -inch blade spacing set to a depth of 0.08 inch (Graden GS04; Graden Co., Victoria, Australia). Following debris removal, the first site was seeded with 'Replay' on 14 Sept. 2009 at $347 \mathrm{lb} /$ acre. The trial was repeated on an adjacent area that was seeded with 'Replay' on 6 May 2010. Both sites' soil profile was a Garrison gravelly silt loam (fine-loamy, mixed, superactive, calcareous, hyperthermic, Typic, Torrifluvent). Plots were fertilized at a yearly rate of 171 lb/acre $\mathrm{N}$ using a $15 \mathrm{~N}-6.6 \mathrm{P}-12.5 \mathrm{~K}$ fertilizer; however, the last application was 1 month before treatment initiation and fertility was not resumed until $30 \mathrm{~d}$ after glyphosate application for both study sites. Once all plots were established, mowing height was 0.50 inch, three times weekly during the growing season without clipping removal. Irrigation was provided as needed to prevent wilt stress and no additional herbicide, fungicide, or insecticide applications were necessary.

Glyphosate (Departure; Syngenta Crop Protection, Greensboro, NC) was applied on 15 July 2010 and 2 Aug. 2012 at 0, 0.13, 0.26, 0.40, 0.52, 0.80 , and $1.03 \mathrm{lb} /$ acre. PGRs flurprimidol (FL), trinexapac-ethyl (TE), PB, and TE + FL were applied on the same dates as glyphosate at $0.50,0.18,0.37$, and $0.09+0.22 \mathrm{lb} /$ acre, respectively. All treatments were applied using a carbon dioxide $\left(\mathrm{CO}_{2}\right)$ backpack sprayer calibrated to deliver $35 \mathrm{gal} / \mathrm{acre}$ set to $245 \mathrm{kPa}$ with XR 8004 nozzles (TeeJet Technologies, Wheaton, IL). Individual plot size was $4 \times 6 \mathrm{ft}$.

Turfgrass quality (TQ) was rated on a scale of $1-9$, where 1 represents brown, dead turfgrass, 7 represents commercially acceptable turfgrass, and 9 represents dark green, healthy turfgrass. This parameter was rated 10 , 20 , and $30 \mathrm{~d}$ after application (DAA). Relative chlorophyll index [RCI (0999)] was recorded 20 DAA using a hand-held reflectance meter (CM 1000; Spectrum Technologies, Plainfield, IL). Each individual reading measured an area $\approx 5.7$ inches wide. Three readings were recorded for each plot and then averaged. Clipping yield (ounces per square foot) was collected 10, 20, and 30 DAA. Following $48 \mathrm{~h}$ of growth, clippings were harvested using a walk-behind greens mower (Greens King 500 Series, Jacobsen). Following harvest, clippings were dried in an oven set to $80^{\circ} \mathrm{C}$ for $48 \mathrm{~h}$, and then weighed.

Tank mixing. A separate field trial at the Jacklin Seed research farm in Post Falls, ID, was seeded on 6 May 2010 at a rate of $347 \mathrm{lb} /$ acre. Treatments were applied over the same plot area for both years of the study. Method of seeding, management practices, plot size, and sprayer equipment were identical to the growth regulation trial described above. Dicamba (Banvel; Arysta LifeScience, Cary, NC) and TE were applied at 0.50 and $0.18 \mathrm{lb} /$ acre, respectively. In addition to the yearly fertilizer rate of $171 \mathrm{lb} /$ acre $\mathrm{N}$ using a $15 \mathrm{~N}-6.6 \mathrm{P}-$ $12.5 \mathrm{~K}$ fertilizer, an additional $15 \mathrm{lb} /$ acre was applied using urea and AMS. Both dicamba and the $\mathrm{N}$ sources were applied alone or tank mixed with glyphosate at $0,0.26$, and $0.52 \mathrm{lb} /$ acre. All treatments were applied on 3 Sept. 2010 and 2 Aug. 2012. PRG color was visually rated 10,22 , and $32 \mathrm{DAA}$ on a scale from 1 to 9 , where 1 represents brown turfgrass and 9 represents dark green turfgrass. Percent ABG was rated on a scale of $0 \%$ to $100 \%$, where $0 \%$ represents no $\mathrm{ABG}$ encroachment and $100 \%$ represents complete ABG encroachment.

Data analysis. In both trials, treatments were arranged in a randomized complete block design with three replications. Treatment effects were evaluated using analysis of variance (ANOVA) with means separation based on Fisher's least significant difference test at alpha $=0.05$ (Statistica; Stat-Soft, Tulsa, OK). For both trials, there was no year by treatment interaction for any parameter measured; therefore, data collected over the 2-year study period were pooled.

\section{Results and discussion}

Growth REgulation TRIAL. There were year by treatment interactions at 20 and $30 \mathrm{DAA}$ for TQ, but not for any other parameter measured (Tables 1 and 2). However, results from year I and II are combined since the differences were scale changes. Year II TQ scores were lower than year I, likely because the stand was in its third growing season and a monostand of PRG is poorly adapted to the climate of northern Idaho. However, glyphosate and PGR treatments were significant for all parameters across all recorded dates.

Regarding $\mathrm{TQ}$, at 10 and 20 DAA, glyphosate rates $>0.52 \mathrm{lb} /$ acre resulted in TQ scores below the acceptable threshold $(<7.0)$ (Table 1$)$. Also, all PGR applications resulted in TQ scores near 8.0 throughout the duration of the research trial. AT 10 DAA, lowest TQ scores were noted at the two highest glyphosate rates. $\mathrm{Al}$ though the $0.52 \mathrm{lb} /$ acre treatment had TQ scores significantly lower than PGRs and glyphosate rates $\leq 0.40 \mathrm{lb} /$ acre, TQ scores still rated a commercially acceptable score of 7.0. Similar trends were noted at 20 DAA; however, the $0.80 \mathrm{lb} /$ acre was statistically similar to the 0.26 and 
Table 1. 'Replay' perennial ryegrass turfgrass quality and relative chlorophyll index following various glyphosate application rates and plant growth regulators on 15 July 2010 and 2 Aug. 2012 in Post Falls, ID.

\begin{tabular}{|c|c|c|c|c|c|}
\hline \multirow[b]{2}{*}{ Treatment } & \multirow[b]{2}{*}{ Rate } & \multicolumn{3}{|c|}{ Turfgrass quality (1-9 scale $)^{\mathrm{z}}$} & \multirow{2}{*}{$\begin{array}{l}\text { Relative chlorophyl } \\
\text { index (0-999 scale) } \\
20 \text { DAA }\end{array}$} \\
\hline & & $10 \mathrm{DAA}^{\mathrm{x}}$ & 20 DAA & 30 DAA & \\
\hline \multirow[t]{4}{*}{ Glyphosate (lb/acre $)^{\mathrm{w}}$} & 0.13 & 8.7 & 8.3 & 8.2 & 344 \\
\hline & 0.26 & 8.7 & 7.3 & 8.3 & 337 \\
\hline & 0.40 & 8.3 & 8.0 & 7.8 & 353 \\
\hline & 1.03 & 5.5 & 5.0 & 7.0 & 272 \\
\hline \multicolumn{6}{|l|}{ Plant growth regulator (lb/acre) } \\
\hline Flurprimidol (FL) & 0.50 & 9.0 & 8.2 & 8.0 & 377 \\
\hline Trinexapac-ethyl (TE) & 0.18 & 9.0 & 7.8 & 8.0 & 352 \\
\hline Paclobutrazol & 0.37 & 9.0 & 7.8 & 7.8 & 358 \\
\hline Treatment $(\mathrm{T})$ & & ** & ** & * & ** \\
\hline $\mathrm{Y} \times \mathrm{T}$ & & NS & ** & ** & NS \\
\hline
\end{tabular}

${ }^{\mathrm{z}} 1$ = brown, dead turfgrass; 7 = commercially acceptable turfgrass; 9 = dark green, healthy turfgrass

${ }^{y}$ Chlorophyll rated using a chlorophyll meter (CM 1000; Spectrum Technologies, Plainfield, IL).

${ }^{x} \mathrm{DAA}=$ days after application

${ }^{\mathrm{w}} \mathrm{l} \mathrm{lb} /$ acre $=1.1209 \mathrm{~kg} \cdot \mathrm{ha}^{-1}$.

${ }^{\mathrm{N} S}=$ Nonsignificant.

*, * Significant at $P \leq 0.05, P \leq 0.01$, respectively.

Table 2. 'Replay' perennial ryegrass clipping yield following various glyphosate application rates and plant growth regulators on 15 July 2010 and 2 Aug. 2012 in Post Falls, ID.

\begin{tabular}{|c|c|c|c|c|}
\hline \multirow[b]{2}{*}{ Treatment } & \multicolumn{4}{|c|}{ Clipping yield $\left(\mathrm{oz} / \mathrm{ft}^{2}\right)^{\mathrm{z}}$} \\
\hline & Rate & $10 \mathrm{DAA}^{\mathrm{y}}$ & 20 DAA & $30 \mathrm{DAA}$ \\
\hline Control & - & 0.048 & 0.038 & 0.013 \\
\hline \multirow[t]{6}{*}{ Glyphosate $(\mathrm{lb} / \text { acre })^{\mathrm{z}}$} & 0.13 & 0.035 & 0.024 & 0.008 \\
\hline & 0.26 & 0.030 & 0.019 & 0.007 \\
\hline & 0.40 & 0.030 & 0.014 & 0.007 \\
\hline & 0.52 & 0.024 & 0.011 & 0.007 \\
\hline & 0.80 & 0.024 & 0.009 & 0.004 \\
\hline & 1.03 & 0.023 & 0.013 & 0.006 \\
\hline \multicolumn{5}{|l|}{ Plant growth regulator (lb/acre) } \\
\hline Flurprimidol (FL) & 0.50 & 0.034 & 0.022 & 0.007 \\
\hline Trinexapac-ethyl (TE) & 0.18 & 0.027 & 0.021 & 0.007 \\
\hline Paclobutrazol & 0.37 & 0.038 & 0.027 & 0.009 \\
\hline $\mathrm{TE}+\mathrm{FL}$ & $0.09+0.22$ & 0.036 & 0.028 & 0.008 \\
\hline Least significant difference $(P=0.05)$ & & 0.0208 & 0.018 & 0.0074 \\
\hline \multicolumn{5}{|l|}{ Analysis of variance } \\
\hline Year $(Y)$ & & ** & $\mathrm{NS}^{\mathrm{x}}$ & ** \\
\hline Treatment $(\mathrm{T})$ & & ** & ** & * \\
\hline $\mathrm{Y} \times \mathrm{T}$ & & NS & NS & NS \\
\hline
\end{tabular}

${ }^{\mathrm{z}} 1 \mathrm{oz} / \mathrm{ft}^{2}=305.1517 \mathrm{~g} \cdot \mathrm{m}^{-2}, \mathrm{l} \mathrm{lb} /$ acre $=1.1209 \mathrm{~kg} \cdot \mathrm{ha}^{-1}$.

${ }^{\mathrm{y}} \mathrm{DAA}=$ days after application.

${ }^{\mathrm{x}} \mathrm{NS}=$ Nonsignificant.

* * * Significant at $P \leq 0.05, P \leq 0.01$, respectively.

$0.52 \mathrm{lb} /$ acre application rates. Although statistically similar, TQ score was below the acceptable threshold of 7.0. By $30 \mathrm{DAA}$, all treatments had TQ scores $\geq 7.0$. Relative chlorophyll index ratings at $20 \mathrm{DAA}$ followed similar trends as TQ scores. Overall, the highest RCI was noted for FL and
$\mathrm{TE}+\mathrm{FL}$ treated plots, whereas the lowest RCI was at glyphosate rates $>0.52 \mathrm{lb} /$ acre. Averaged across all glyphosate rates, the 0.80 and 1.03 $\mathrm{lb} /$ acre rates showed a $21 \%$ and $26 \%$ decrease in RCI, respectively. Meanwhile, glyphosate rates $\leq 0.52 \mathrm{lb} /$ acre RCI was similar to untreated plots.
At 10 DAA, among PGR treated plots, only TE showed a significant growth reduction compared with the control (Table 2). By 20 and 30 DAA, PGR treatments numerically reduced growth; however, statistical differences were not noted. At 10 and 20 DAA, glyphosate rates $>0.40$ and $\geq 0.26 \mathrm{lb} /$ acre, respectively, resulted in a significant growth reduction compared with the control. However, only rates $\leq 0.52 \mathrm{lb} /$ acre provided acceptable TQ at 10 and 20 DAA (Table 1). By 30 DAA, with the exception of the $0.80 \mathrm{lb} /$ acre glyphosate rate, all growth regulation effects from the PGR and glyphosate treatments were not detected.

Although glyphosate is considered a class D PGR (Ervin and Zhang, 2008 ), to the authors knowledge, no studies have quantified its growth regulating effects in turfgrass since the use of glyphosate-tolerant cultivars in the turfgrass industry is not widespread. In this study, the most consistent growth regulating glyphosate rate, while maintaining acceptable TQ, was noted at the $0.52-\mathrm{lb} /$ acre rate as its suppression was greater than the control on two of the three clipping collection dates. Although all glyphosate rates in this study reduced clipping yield, Velini et al. (2008) noted sublethal rates of glyphosate 
stimulated growth in nonglyphosateresistant maize (Zea mays L.) and soybean plants. However, in the glyphosate-resistant soybean plants, growth stimulus was not observed. The authors noted that the growth stimulus may be related to the inhibition of 5-enolpyruvylshikimate3 -phosphate synthase (EPSPS) due to increased shikimate accumulation in the nonglyphosate-resistant plants. In resistant plants (lack of growth stimulus), the authors noted a lack of shikimate accumulation, therefore an insensitive EPSPS, may be the leading reason for a lack of a growth stimulus. Since the glyphosate tolerance of the PRG plants is associated with double mutations of the EPSPS gene and its encoded EPSPS protein (Samudio et al., 2011), this is likely why an increase in growth was not observed. In turfgrass research, numerous studies have documented PGRs effect on clipping yield, but few have used PRG as the selected species (Pannacci et al., 2004; Tegg and Lane, 2004). In this study, TE showed a significant growth reduction compared with controls, whereas FL, PB, and TE + FL did not, which is likely due to the different mode of action of each PGR (Ervin and Zhang, 2008). It is possible that FLand PB-treated plots would have shown a significant growth reduction if clipping yield was collected beyond
30 DAA since these PGRs inhibit gibberellic acid biosynthesis early in the biosynthetic pathway and have a different absorption preference than TE. Applying glyphosate at $0.52 \mathrm{lb} /$ acre, while maintaining acceptable TQ, can be expected to provide comparable growth regulation relative to current industry standard PGRs. The growth regulating effects (i.e., less mowing) from glyphosate applications observed in this trial would be an additional benefit to ABG control due to reductions in labor, equipment maintenance, and emission output that are all associated with mowing.

TANK MIX TRIAL. Regarding PRG color, at 10 and $22 \mathrm{DAA}$, there was a significant glyphosate rate, dicamba, and $\mathrm{N}$ source main effect; however, TE did not have a significant effect on PRG color (Table 3). There were however, several treatment interactions. The significant three-way interaction of glyphosate rate, dicamba, and $\mathrm{N}$ source will be presented at 10 and 32 DAA. At 22 DAA, the significant two-way interaction of glyphosate rate by dicamba and glyphosate rate by $\mathrm{N}$ source will be presented.

At 10 DAA, PRG color following glyphosate applied at 0 and 0.26 $\mathrm{lb} /$ acre was $>7$ with minimal influence from tank mixing dicamba and $\mathrm{N}$ sources (Table 4). The lowest color rating (6.4) was observed at the highest application rate of glyphosate

Table 3. Analysis of variance for glyphosate rate, dicamba, trinexapac-ethyl, and nitrogen sources on the color of 'Replay' perennial ryegrass and percent annual bluegrass (ABG) following an application in Post Falls, ID.

\begin{tabular}{|c|c|c|c|c|c|}
\hline \multirow[b]{2}{*}{ Main factors } & \multicolumn{3}{|c|}{ Perennial ryegrass color } & \multicolumn{2}{|c|}{ ABG (\%) } \\
\hline & $10 \mathrm{DAA}^{\mathrm{z}}$ & 22 DAA & $32 \mathrm{DAA}$ & $22 \mathrm{DAA}$ & $32 \mathrm{DAA}$ \\
\hline Glyphosate rate (GR) & ** & ** & $\mathrm{NS}^{\mathrm{y}}$ & ** & ** \\
\hline Dicamba $(\mathrm{D})^{\mathrm{x}}$ & ** & * & NS & NS & NS \\
\hline Trinexapac-ethyl $(\mathrm{TE})^{\mathrm{x}}$ & NS & NS & NS & ** & ** \\
\hline Nitrogen source $(\mathrm{NS})^{\mathrm{x}}$ & ** & ** & ** & NS & NS \\
\hline $\mathrm{GR} \times \mathrm{D}$ & NS & * & NS & * & NS \\
\hline $\mathrm{GR} \times \mathrm{TE}$ & * & NS & NS & * * & ** \\
\hline $\mathrm{GR} \times \mathrm{NS}$ & * & * & NS & * & NS \\
\hline $\mathrm{D} \times \mathrm{TE}$ & NS & NS & NS & NS & NS \\
\hline $\mathrm{D} \times \mathrm{NS}$ & ** & NS & * & NS & NS \\
\hline $\mathrm{PGR} \times \mathrm{NS}$ & NS & NS & NS & NS & NS \\
\hline $\mathrm{GR} \times \mathrm{D} \times \mathrm{TE}$ & NS & NS & NS & NS & NS \\
\hline $\mathrm{GR} \times \mathrm{D} \times \mathrm{NS}$ & * & NS & * & NS & NS \\
\hline $\mathrm{GR} \times \mathrm{TE} \times \mathrm{NS}$ & NS & NS & NS & ** & NS \\
\hline $\mathrm{D} \times \mathrm{TE} \times \mathrm{NS}$ & NS & NS & NS & NS & NS \\
\hline $\mathrm{GR} \times \mathrm{D} \times \mathrm{TE} \times \mathrm{NS}$ & NS & NS & NS & NS & NS \\
\hline
\end{tabular}

${ }^{\mathrm{z}} \mathrm{DAA}=$ days after application.

$\mathrm{y}_{\mathrm{NS}}=$ Nonsignificant.

${ }^{x} \mathrm{D}$ applied at $0.50 \mathrm{lb} / \mathrm{acre}$, TE applied at $0.18 \mathrm{lb} / \mathrm{acre}, \mathrm{NS}=$ urea and ammonium sulfate applied at $15 \mathrm{lb} / \mathrm{acre} ; \mathrm{l}$ $\mathrm{lb} /$ acre $=1.1209 \mathrm{~kg} \mathrm{ha}^{-1}$.

*, ** Significant at $P \leq 0.05, P \leq 0.01$, respectively.
(0.52 lb/acre). However, the addition of AMS as well as the addition of dicamba + urea significantly improved PRG color compared with glyphosate alone at the $0.52-\mathrm{lb} /$ acre rate. At 22 DAA, the lowest ratings were noted at the $0.52 \mathrm{lb} /$ acre glyphosate rate. However, $\mathrm{N}$ source significantly influenced PRG color. Although all color ratings were above 7 , the addition of AMS at the $0.52 \mathrm{lb} /$ acre glyphosate rate significantly improved color compared with glyphosate alone. At 32 DAA following a 0.52 $\mathrm{lb} /$ acre glyphosate application, the addition of dicamba + AMS significantly enhanced PRG color compared with dicamba and dicamba + urea. At no time in the study did the addition of a $\mathrm{N}$ source impact PRG color when glyphosate was applied at 0 or 0.26 $\mathrm{lb} / \mathrm{acre}$. Also, the addition of TE did not influence color ratings at any rating date. Regardless of glyphosate application rate, the addition of TE, $\mathrm{N}$ sources, and dicamba did not reduce PRG color on any rating dates.

Regarding percent $A B G$, at 22 DAA and 32 DAA, the main factors of glyphosate rate and TE were significant; however, dicamba and $\mathrm{N}$ source were not significant (Table 3 ). There were, however, several treatment interactions. The three-way interaction of glyphosate rate, $\mathrm{TE}$, and $\mathrm{N}$ source was significant at $22 \mathrm{DAA}$, whereas the glyphosate rate by TE interaction was significant at $32 \mathrm{DAA}$.

At 22 DAA, excellent ABG control was observed $(<10 \%)$ at the 0.26 and $0.52 \mathrm{lb} /$ acre glyphosate application rate, regardless of $\mathrm{N}$ source or the addition of TE (Table 5). Overall, without glyphosate, the greatest $A B G$ encroachment was noted in plots without TE compared with TEtreated PRG. Specifically, without the addition of TE, urea-treated plots had $42 \%$ and $65 \%$ greater ABG compared with plots treated with AMS or untreated with a $\mathrm{N}$ source, respectively. Similar to $22 \mathrm{DAA}$, excellent ABG control was observed $(<10 \%) 32$ DAA at the 0.26 and $0.52 \mathrm{lb} /$ acre glyphosate application rate. However, in the absence of glyphosate, TE-treated plots reduced ABG encroachment by $19 \%$.

Overall, tank mixing urea with glyphosate at the $0.52-\mathrm{lb} /$ acre rate had little effect on PRG color, whereas the addition of AMS consistently improved color at the highest 
Research Reports

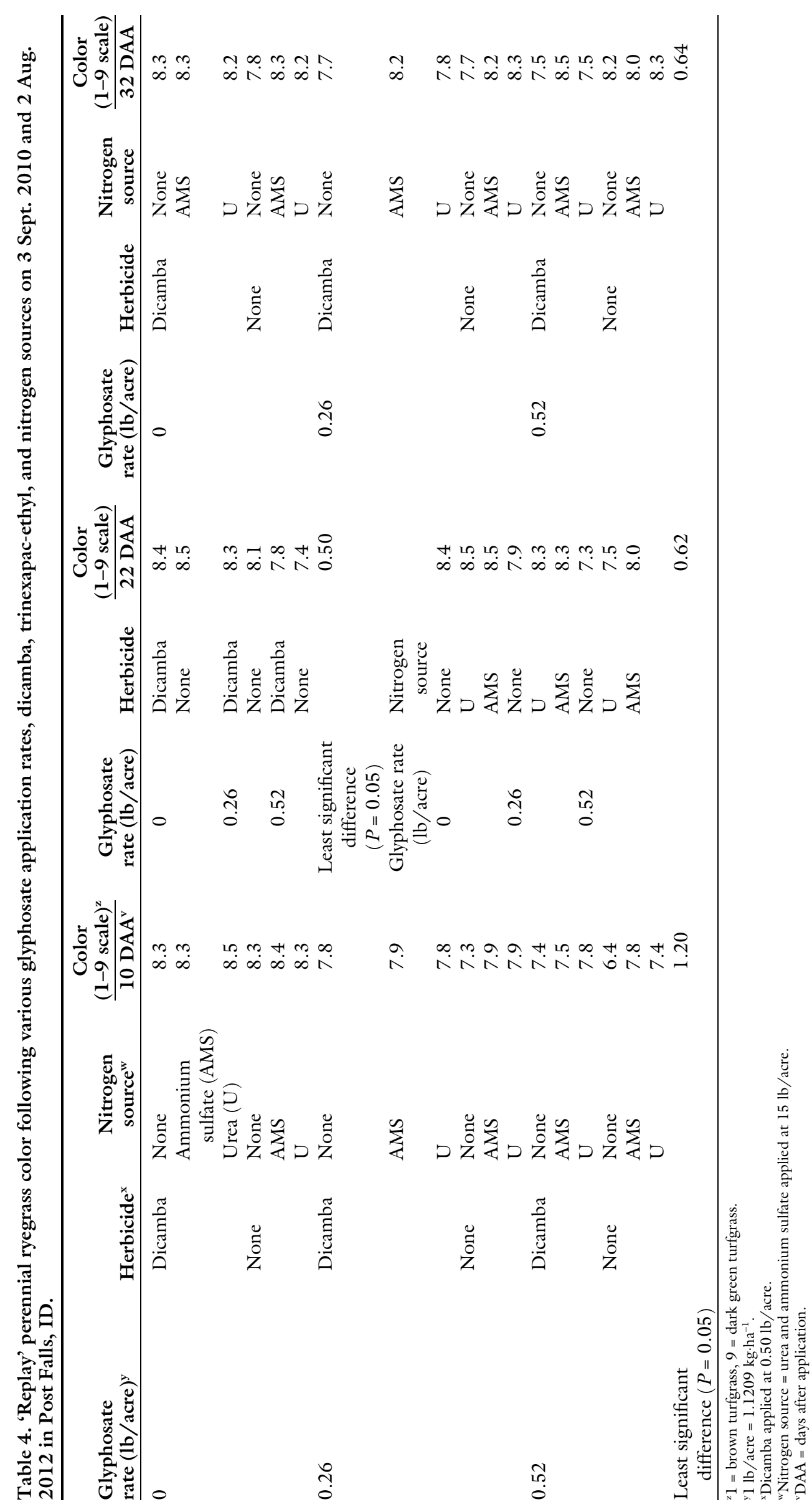

218

Horllechnology · April 2015 25(2) 
Table 5. Percent annual bluegrass (ABG) following various glyphosate application rates, trinexapac-ethyl (TE), and nitrogen sources following an application on 3 Sept. 2010 and 2 Aug. 2012 in Post Falls, ID.

\begin{tabular}{|c|c|c|c|c|c|c|}
\hline $\begin{array}{l}\text { Glyphosate } \\
\text { rate }(\text { lb } / \text { acre })^{z}\end{array}$ & $\mathrm{TE}^{\mathrm{y}}$ & $\begin{array}{l}\text { Nitrogen } \\
\text { source }^{\mathrm{x}}\end{array}$ & $\frac{\mathrm{ABG}(\%)}{22 \mathrm{DAA}^{\mathrm{w}}}$ & $\begin{array}{l}\text { Glyphosate } \\
\text { rate (lb/acre) }\end{array}$ & TE & $\frac{\mathrm{ABG}(\%)}{32 \mathrm{DAA}}$ \\
\hline \multirow[t]{3}{*}{0} & $\mathrm{TE}$ & None & 20.0 & 0 & $\mathrm{TE}$ & 46.8 \\
\hline & & Urea $(\mathrm{U})$ & 18.3 & 0.26 & TE & 3.5 \\
\hline & None & None & 25.8 & & None & 4.9 \\
\hline \multirow[t]{5}{*}{0.26} & $\mathrm{TE}$ & None & 0.0 & $\begin{array}{l}\text { Least significant } \\
\quad \text { difference }(P=0.05)\end{array}$ & & 8.53 \\
\hline & & AMS & 0.8 & & & \\
\hline & & $\mathrm{U}$ & 2.5 & & & \\
\hline & None & None & 5.8 & & & \\
\hline & & AMS & 1.7 & & & \\
\hline \multirow{4}{*}{0.52} & & $\mathrm{U}$ & 0.0 & & & \\
\hline & None & None & 0.8 & & & \\
\hline & & AMS & 0.0 & & & \\
\hline & & $\mathrm{U}$ & 0.0 & & & \\
\hline $\begin{array}{l}\text { Least significant } \\
\quad \text { difference }(P=0.05)\end{array}$ & & & 7.70 & & & \\
\hline
\end{tabular}

applied glyphosate rate. This could be related to the lack of irrigation following applications. Irrigation was withheld for greater than $4 \mathrm{~h}$ following applications to ensure sufficient time for glyphosate absorption. This may have resulted in significant urea loss through volatilization, which was reported in another trial (Brosnan et al., 2010). Titko et al. (1987) previously reported up to $60 \%$ volatilization losses following a urea application on kentucky bluegrass (Poa pratensis L.) when irrigation was withheld following an application. The addition of AMS at the high rate of glyphosate consistently improved PRG color response across all rating dates; therefore, this may increase the margin of error if a higher application rate is desired or in case of spray overlaps at recommended rates. Future research involving nutrient management during or following glyphosate applications may further improve the response of this cultivar to higher rates of glyphosate.

The addition of AMS or urea did not improve ABG control. There are previous conflicting reports regarding $\mathrm{N}$ fertility and efficacy of weed control following applications of glyphosate or other active ingredients Bradley et al. (2000) did not detect increased control of 'Rox Orange' forage sorghum following a glyphosate application at $75 \mathrm{lb} /$ acre with or without AMS at $3.4 \mathrm{lb} /$ acre. However, the authors did note increased control at a lower glyphosate rate of $0.38 \mathrm{lb} /$ acre tank mixed with AMS. Young et al. (2003) used similar glyphosate rates and did not note improved common lambsquarters control, but reported improved velvetleaf control with the addition of AMS. Cathcart et al. (2004) reported velvetleaf required nearly double the glyphosate rate to reduce shoot biomass by $50 \%$ in a low $\mathrm{N}$ vs. a high $\mathrm{N}$ environment, which is likely due to reduced transport of glyphosate from mature leaves (Mithila et al., 2008). Similarly, Pline et al. (2000) noted the addition of AMS to glyphosate increased efficacy on horsenettle (Solanum carolinense L.), but not on common milkweed (Asclepias syriaca L.) or other various annual weeds. It appears the addition of $\mathrm{N}$ sources when applying glyphosate is dependent on the desired weed species regarding glyphosate efficiency. Results may be impacted by reduced translocation of herbicides within the plant or could be related to the $\mathrm{N}$ status of the desired weed (Cathcart et al., 2004). In this study, it is difficult to truly conclude the effectiveness of adding $\mathrm{N}$ sources with glyphosate since excellent ABG control $(<10 \%)$ was noted at the 0.26 and $0.52 \mathrm{lb} /$ acre glyphosate rate without the addition of other $\mathrm{N}$ sources. Increasing glyphosate rate has previously been reported to eliminate any possible positive effects of tank mixing AMS with glyphosate (Selleck and Baird, 1981). Future studies should investigate lower glyphosate application rates tank mixed with AMS to determine if lower glyphosate rates could be used to improve plant safety and still provide acceptable ABG control. Also, this may possibly extend the application window later in the season since the glyphosate-tolerant PRG cultivars can only tolerate a glyphosate rate up to $0.19 \mathrm{lb} /$ acre when applied in the fall season (Baldwin et al., 2015) compared with a rate of $0.72 \mathrm{lb} /$ acre in the summer season (Baldwin et al., 2012). Regardless, the addition of AMS did not cause additional injury to the PRG cultivar, which is a similar finding for other glyphosate-tolerant agronomic crops (Pline et al., 2000). 


\section{Conclusions}

Results indicate that adding an alternative active ingredient, a PGR, and $\mathrm{N}$ sources do not cause additional injury to the glyphosate-tolerant cultivar. Also, applying glyphosate at $0.52 \mathrm{lb} /$ acre resulted in similar growth reductions compared with industry standard PGRs, while maintaining acceptable TQ. In some cases, the addition of $\mathrm{N}$ sources and a PGR improved the color response and increased $A B G$ control relative to using glyphosate alone. These are vital management strategies to improve PRG safety following a glyphosate application and to further minimize the possibility of developing resistant ABG biotypes, which have been previously reported on golf courses in Tennessee and Missouri following repeated use of glyphosate (Binkholder et al., 2011; Brosnan et al., 2012). Future studies should investigate tank mixing with other herbicide active ingredients and investigating $\mathrm{N}$ rates and sources to further improve safety and increase $A B G$ control following glyphosate applications. This type of research is needed to improve ABG control and provide more protection and broader application rates to lessen the risk of PRG discoloration following an application by the turfgrass practitioner.

\section{Literature cited}

Baldwin, C.M., A.D. Brede, and J.J. Mayer. 2012. 'JS501' and 'Replay' perennial ryegrass glyphosate tolerance and rates required for annual bluegrass (Poa annua L.) control. HortScience 47:932935.

Baldwin, C.M., E.K. Blythe, A.D. Brede, J.J. Mayer, and R. Golembiewski. 2015. Glyphosate tolerance of two perennial ryegrass cultivars from fall applications and at seedling growth stages. HortScience 50:304-309.

Binkholder, K.M., B.S. Fresenburg, T.C. Tueton, X. Xiong, and R.J. Smeda. 2011. Selection of glyphosate-resistant annual bluegrass (Poa annua) on a golf course. Weed Sci. 59:286-289.

Brosnan, J.T., A.W. Thoms, P.E. McCullough, G.R. Armel, G.K. Breeden, J.C. Sorochan, and T.C. Mueller. 2010.
Efficacy of flazasulfuron for control of annual bluegrass (Poa annua) and perennial ryegrass (Lolium perenne) as influenced by nitrogen. Weed Sci. 58:449-456.

Brosnan, J.T., G.K. Breeden, and T.C. Mueller. 2012. A glyphosate-resistant biotype of annual bluegrass in Tennessee. Weed Sci. 60:97-100.

Bradley, P.R., W.G. Johnson, and R.J. Smeda. 2000. Response of sorghum (Sorghum bicolor) to atrazine, ammonium sulfate, and glyphosate. Weed Technol. 14:15-18.

Cakmak, I., A. Yazici, Y. Tutus, and L. Ozturk. 2009. Glyphosate reduced seed and leaf concentrations of calcium, manganese, magnesium, and iron in nonglyphosate resistant soybean. Eur. J. Agron. 31:114-119.

Cathcart, R.J., K. Chandler, and C.J. Swanton. 2004. Fertilizer nitrogen rate and the response of weeds to herbicides. Weed Sci. 52:291-296.

Dant, L.A., N.E. Christians, and S.Z. Fei. 2005. Timing of Roundup ${ }^{\circledR}$ application critical when converting golf course turf to Roundup Ready ${ }^{\circledR}$ creeping bentgrass. Intl. Turfgrass Soc. Res. J. 10:333-338.

Elmore, M.T., J.T. Brosnan, G.K. Breeden, and A.J. Patton. 2013. Mesotrione, topramezone, and amicarbazone combinations for postemergence annual bluegrass (Poa annua) control. Weed Technol. 27:596-603.

Ervin, E.H. and X. Zhang. 2008. Applied physiology of natural and synthetic plant growth regulators on turfgrasses, p. 171200. In: M. Pessarakli (ed.). Handbook of turfgrass management and physiology. Taylor and Francis, Boca Raton, FL.

Flessner, M.L., J.S. McElroy, and G.R. Wehtje. 2014. Annual bluegrass (Poa annua) control in glyphosate-resistant perennial ryegrass overseeding. Weed Technol. 28:213-224.

Hart, S.E., J.F. Derr, D.W. Lycan, C. Rose-Fricker, and W.A. Meyer. 2005. Increased glyphosate tolerance in 'Aurora Gold' hard fescue (Festuca longifolia). Weed Technol. 19:640-646.

Jeffries, M.D., F.H. Yelverton, and T.W. Gannon. 2013. Annual bluegrass (Poa anmua) control in creeping bentgrass putting greens with amicarbazone and paclobutrazol. Weed Technol. 27:520526.
Kaminski, J.E. and A.I. Putman. 2009. Safety of bispyribac-sodium on colonial bentgrass and influence on brown patch severity. Intl. Turfgrass Soc. Res. J. 11: 219-226.

Mithila, J., C.J. Swanton, R.E. Blackshaw, R.J. Cathcart, and J.C. Hall. 2008. Physiological basis for reduced glyphosate efficacy on weeds grown under low soil nitrogen. Weed Sci. 56:12-17.

Pannacci, E.G., G. Corvarelli, and F. Tei. 2004. Evaluation of trinexapac-ethyl for growth regulation of five cool-season turfgrass species. ISHS Acta Hort. 661:349-351.

Pline, W.A., K.K. Hatzios, and E.S. Hagood. 2000. Weed and herbicideresistant soybean (Glycine max) response to glufosinate and glyphosate plus ammonium sulfate and pelargonic acid. Weed Technol. 14:667-674.

Samudio, S., A.D. Brede, J. Ye, and C. Rommens. 2011. Breeding and development of JS501 and Replay glyphosatetolerant perennial ryegrass. 26 Jan. 2015. $<$ https://scisoc.confex.com/crops/ $201 \mathrm{lam} /$ webprogram/Paper64580. html> (Abstr.).

Schilling, B.S., K.N. Harker, and J.R. King. 2006. Glyphosate can reduce glyphosate-resistant canola growth after individual or sequential applications. Weed Technol. 20:825-830.

Selleck, G.W. and D.D. Baird. 1981. Antagonism with glyphosate and residual herbicide combinations. Weed Sci. 29:185-190.

Tegg, R.S. and P.A. Lane. 2004. Shade performance of a range of turfgrass species improved by trinexapac-ethyl. Austral. J. Expt. Agr. 44:939-945.

Titko, S., III, J.R. Street, and T.J. Logan. 1987. Volitalization of ammonia from granular and dissolved urea applied to turfgrass. Agron. J. 79:535-540.

Velini, E.D., E. Alves, M.C. Godoy, D.K. Meschede, R.T. Souza, and S.O. Duke. 2008. Glyphosate applied at low doses can stimulate plant growth. Pest Mgt. Sci. 64:489-496.

Young, B.G., A.W. Knepp, L.M. Wax, and S.E. Hart. 2003. Glyphosate translocation in common lambsquarters (Chenopodium album) and velvetleaf (Abutilon theophrasti) in response to ammonium sulfate. Weed Sci. 51:151-156. 